\title{
Regulating the European Union internal market: between crisis and business as usual
}

\author{
Michele Messina
}

Published online: 18 August 2010

(C) ERA 2010

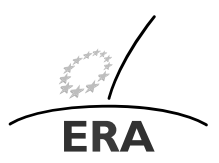

EUROPÄISCHE RECHTSAKADEMIE ACADEMY OF EUROPEAN LAW ACADEMIE DE DROIT EUROPEEN ACCADEMIA DI DIRITTO EUROPEO TRIER - TREVES - TREVIRI

\section{Why regulation should prevail over laissez-faire}

The outbreak of the financial and later economic crisis in 2008 produced mixed and at times contradictory feelings in the business law community. On the one hand, the importance of regulating the specific markets in question is considered as a conditio sine qua non for their stability as a whole. On the other hand, other areas of law are considered as overregulated, putting into serious doubt, if not at risk, important features of the European Union's internal market. This point clearly applies regarding competition law rules in general, and to state aid rules, more specifically. The latter, in particular, have been considered too restrictive in times of crisis, leading to calls for the need to ease, if not entirely suspend their application. ${ }^{1}$ In particular, in the aftermath of the collapse of Lehman Brothers, much pressure was brought to bear in favour of the setting aside of competition rules on state aid, in order to allow European Union member states freedom to implement financial sector rescue measures they considered to be necessary in the circumstances. However, the concerns have since then revealed themselves to have been excessive and the existing rules to have been all the more necessary, if not indispensable, for dealing with the emergency. To this end, the effort made by the European Commission has been absolutely remarkable, in particular through its adoption of landmark communications giving needed

\footnotetext{
${ }^{1}$ As highlighted by the former Competition Commissioner Neelie Kroes, "competition policy may not be loved by all governments and competitors, but the need for it to act as the backbone of the EU Single Market remains substantially unchallenged." See N. Kroes, Competition policy and the crisis-the Commission's approach to banking and beyond, in Competition Policy Newsletter, n. 1, 2010.
}

Dr. M. Messina, Course Director $(\bowtie)$

Academy of European Law, Metzer Allee 4, 54295 Trier, Germany

e-mail: mmessina@era.int 
guidance on the application of existing rules in this time of crisis, and showing a sound pragmatism in balancing substantial flexibility as regards means on the one hand with preserving consistency insofar as concerns the principles, on the other. ${ }^{2}$

I personally share the view that rules are all the more important in times of crisis. They may perhaps need to be adapted to the specific given circumstances. Their existence and necessity, however, should not be put at risk. During a recession, the setting aside of relevant rules and competition rules, in particular, would have the effect of delaying economic recovery, thereby increasing the already high costs of the crisis, if not paving the way for a more complicated depression.

For all the reasons above, competition authorities, in cooperation with sectorspecific authorities, and, as we learnt from the crisis, central banks (at least for the financial sector) should play an important role in the debate on new forms of regulations, in order to ensure they do not impose restrictions on competition which are not strictly necessary for the attainment of the economic and non-economic objectives on which they are based. Self-regulation in the financial sector did not seem to work, thus the key elements of new regulations must involve greater transparency and better supervision. Competition authorities should also have an important role in setting up aid and rescue plans for struggling enterprises or sectors, in order to avoid distortions of competition in the relevant markets. In fact, such plans, by producing artificial income, decrease the overall efficiency of enterprises, thus making even more difficult the recovery in the real economic markets. Furthermore, competition authorities should prevent every attempt, however minor, by member states to bring about a resurgence of protectionism.

In consequence of the foregoing, regulatory supervision of the financial sector at European Union level is considered to be necessary, in the form of the likely establishment of supervisory authorities at European level, in particular in the banking, securities and insurance sectors, in addition to the establishment of a European Systemic Risk Board. ${ }^{3}$ As illustrated by Professor Niamh Moloney in her contribution to this issue of the Forum, although the preoccupation with stabilising markets and getting the banking system over the financial crisis has been overwhelming, there have nevertheless also been some important indications that retail interest has not been entirely overlooked either. Those indications are twofold: April 2009 saw the publication of the important Commission Communication on Packaged Retail Investment Products

\footnotetext{
${ }^{2}$ On that occasion, the Commission for the first time invoked Article 87(3)(b) EC Treaty (now Article 107(3)(b) TFEU), according to which state aid may be considered permissible "to remedy a serious disturbance in the economy of a Member State". The speed in adopting the necessary decisions was of key importance. In fact decisions not to raise objections regarding state measures in support of financial institutions were taken within weeks, even a few days, although under normal circumstances, cases of such impact and complexity would probably have been submitted to a formal procedure. The impact is all the more evident when we consider that, normally, the preliminary examination period for notified state aid is two months, according to Article 4(5) of Regulation 659/1999, followed by a formal investigation period of another eighteen months, with the possibility of further extension, according to Article 7(6) of Regulation 659/1999. See Editorial Comment: From rescue to restructuring: The role of state aid control for the financial sector, in Common Market Law Review, vol. 47, 2010, pp. 313-318.

${ }^{3}$ The European Union financial supervision package, largely inspired by the Report by the High-Level Group on Financial Supervision in the European Union-better known as the de Larosière Report-is now contained in five draft legislative acts.
} 
(PRIPS), while a major and radical recast of the European Union's harmonised disclosure and advice/sales rules concerning investment products is now underway. The Communication on Packaged Retail Investment Products in particular forms part of a continuum with the strenuous efforts which had already been made prior to the crisis to build a retail regulatory regime. Furthermore, the Commission commitment to this initiative appears all the more real in the wake of Commissioner Barnier's statement in his first address to the ECOFIN Council in February 2010, where he affirmed that financial regulation is also about "improving the daily life of European citizens". As Professor Moloney affirms, the Packaged Retail Investment Products initiative is striking in its ambition and reflects the European Union's enthusiasm for retail market regulation, although its success will depend on whether the temptation to design a regime which simply provides for regulatory tidiness "on the books" is avoided.

In the aftermath of the financial crisis, the European Union member states have undergone a long process of adoption of recovery plans at national level. In this issue of the Forum, Conor Quigley gives account of the measures adopted in the Republic of Ireland through the establishment of the National Assets Management Agency (NAMA), a step announced by the Irish Minister of Finance in April 2009, followed by draft legislation and then the approval of the European Commission, after several commitments were provided by the Irish Government. NAMA was established to address Ireland's economic woes-brought about by straightforward excesses in the Irish property development sector. In fact, the main problem preventing banks from raising capital on the financial markets was the massive element of bad loans on their books from the property development sector. To deal with this, the Irish Government decided to establish a bad bank which would take over these loans, freeing up the banks from the debt so as to be able to start again and raise fresh capital. The intention of NAMA is to sell off the thousands of properties that are subject to the loans over the next ten years. Although the Commission had little difficulty in determining that the NAMA scheme constituted a state aid, since the purchase of the assets was financed up to $95 \%$ by state- guaranteed bonds, the Commission had also little difficulty in approving the measure as being aid which was intended to remedy a serious disturbance in the economy of a member state, pursuant to Article 107(3)(b) TFEU. The Commission also considered the scheme in line with the communication on impaired assets, ${ }^{4}$ in particular the provisions governing burden-sharing, behavioural constraints and eligibility, and valuation of assets. As Quigley stresses, the Commission was satisfied with NAMA although it imposed some significant conditions to make the scheme in question as temporary and as transparent as possible, such as, inter alia, the notification of each individual tranche of transferred assets, the submission of a restructuring plan within three months of access to the scheme, and the provision of a report on the functioning of the scheme to the Commission every six months.

\footnotetext{
${ }^{4}$ See the Communication from the Commission on the treatment of impaired assets in the Community banking sector, OJ C 72, 26.03.2009, p. 1.
} 


\section{Some important developments in the internal market for businesses}

This issue of ERA Forum, which concerns the broad area of business law, however, tries not to concentrate exclusively on the financial and economic crisis but also to identify some developments in other key sectors of the European Union internal market, such as in the fields of state aid (in particular procedural issues), public procurement (with a focus on public-private partnerships and the recent adoption of a special regime for the defence sector), intellectual property and competition law (focusing on a much needed summary or synthesis of the existing case law, and car designs) together with all the difficulties related to the lack of consistency in the enforcement of the relevant European Union rules.

\subsection{Procedural issues in state aid}

In its 2005 State Aid Action Plan, ${ }^{5}$ the Commission proposed a comprehensive reform package, which included the need for more effective procedures, better enforcement, higher predictability, and enhanced transparency. Following the State Aid Action Plan, the Commission introduced revised and new legislation as well as guidance documents relating to state aid, including a Code of Best Practice. ${ }^{6}$ Although this has certainly led to an improvement in state aid procedures, according to Nordlander and Went, it is questionable whether the reforms have been sufficient to address the shortcomings and inefficiencies in the procedures flowing from the marginal role given to aid recipients and interested third parties. The contribution to this issue of the Forum by Kristina Nordlander and David Went (drawing inspiration from the recent Opinion by Advocate General Mengozzi in the Scott Paper case which once again calls into question the procedural fairness of the European Commission's state aid procedures $^{7}$ ) examines issues of due process in state aid cases and suggests that it may now be time to consider fundamental procedural reform. The two authors give some good reasons for doing this. Firstly, because the European Courts have still to rely on the principle of sound administration in order to give to aid recipients a role in Commission procedure. Secondly, because the Charter of Fundamental Rightsmade legally binding by the Treaty of Lisbon-contains in Article 41 the principle of good administration (whose essential implications are the right of every person to be heard before any measure is taken that would affect him adversely, the right to have access to the file and the obligation of the administration to give reasons for its decisions). Thirdly, because a clearer role to aid recipients and interested third parties in state aid procedures would not merely be beneficial to them, but more importantly would increase the efficiency and robustness of state aid procedures. Finally because, given the recent explosion in the number of complaints against state aid, an increased role for aid recipients and third parties would render procedures for dealing with complaints fairer and more timely, as a heavier involvement of aid recipients in the

\footnotetext{
${ }^{5}$ State Aid Action Plan-Less and better targeted state aid: a roadmap for state aid reform 2005-2009, COM [2005] 107 final.

${ }^{6}$ Code of Best Practice for the conduct of state aid control procedures, OJ [2009] C 136, p. 13.

${ }^{7}$ See Case C-290/07P European Commission v. Scott SA, Opinion delivered on 23 February 2010.
} 
state aid procedure would likely ease the burden on the Commission when seeking to obtain detailed information.

As highlighted by Advocate General Mengozzi, there is a progressive trend in the case law of the General Court towards a departure from an excessively formalistic interpretation of the Commission state aid obligations, for example insofar as concerns not permitting alleged aid recipients to comment outside the time for submitting comments. According to Nordlander and Went, this trend constitutes a recognition that the rights of aid recipients should be extended at least to ensure that the principle of good administration is observed. However, although the latter principle might not be sufficient to protect the rights of aid recipients, the Commission has at least been put on notice that it should do more to ensure that the rights of aid recipients are given proper protection. In the Scott Paper case, Advocate General Mengozzi concluded that, in that case, the principle of good administration, as embodied in Article 41 of the Charter of Fundamental Rights, might be sufficient to require a voice be given to aid recipients. It remains yet to be seen whether that would always be sufficient and whether the Court of Justice in its forthcoming final judgment will uphold the Advocate General's Opinion, thus giving fresh new impetus to the reform of the locus standi rules in state aid cases.

\subsection{Recent developments in the field of public procurement}

In the field of public procurement, the phenomenon of public private partnerships is of great interest. Professor Christopher Bovis describes it as representing a genuine attempt to revolutionise the delivery of public services by introducing the private sector as a strategic investor in, and financier of, public services. The idea behind such an approach, where the private sector assumes a direct responsibility in serving the public interest, as part of its contractual obligations vis-à-vis the public sector, focuses on the benefits which would follow as a result of the private sector's involvement in the delivery of public services. Professor Bovis identifies those benefits, with efficiency gains, qualitative improvement, innovation, value-for-money and flexibility being the most important ones, whereas an overall better allocation of public resources sums up the advantages of engaging with the private sector in delivering public services. However, the scope for competition in the activities undertaken by public-private partnerships is more limited as compared to public procurement through tendering. Professor Bovis, in the final part of his contribution, affirms the paramount importance of incentive-based regulation where public-private partnerships can operate in a competitive environment globally, safeguarding the principles of transparency and accountability in public sector management. In fact, where a private sector operator can sell public services to the public, but there is little scope for competition, the public sector must regulate prices. Therefore, the challenge ahead is to design wellfunctioning regulation which increases output, stabilises prices and limits monopoly profit while preserving the incentive for private sector to be more efficient and reduce costs.

Still in the field of public procurement law, of great ongoing interest is the adoption of the rules on defence procurement of which Ciara Kennedy-Loest and Nicolas Pourbaix give a detailed account in this issue of the Forum. As the authors affirm, the 
adoption of the European Union Defence Procurement Directive in July 2009 represented the biggest shake-up of defence purchasing in recent times. Although the new regime will not be fully applicable before 21 August 2011, when the Directive has been implemented by member states, the authors provide an interesting overview of the reasons behind the adoption of the Directive and how it tries to address the problems related to the existing applicable regime. The main objective of the Directive is to remedy an existing and long-standing lack of effective cross-border competition on the defence procurement market within the European Union, the result of excessive reliance on Article 346 TFEU, which exempts the majority of public contracts awarded in the defence sector, not only from procurement rules, but from the scope of application of the TFEU as a whole. Nevertheless, as the authors point out, the application of the Directive remains in any case subject to Article 346 TFEU, thus possibly giving rise to a difficult coexistence, rendered more difficult still by the use of some rather confusing wording in the two sets of provisions. It is still too early to assess the effectiveness of the new Directive on Defence Procurement and, as the authors say, only time will tell whether the Directive has struck the right balance between ensuring open competition and safeguarding national security interests, and has managed to reduce reliance on Article 346 TFEU, while providing a framework that is workable and acceptable to Governments and the defence industry.

\subsection{The relationship between European competition law and intellectual property} rights: the need for a summary of European Union case law

From the time of the very first cases concerning the relationship between competition law and intellectual property rights, a substantial difficulty emerged in reconciling the respective objectives of the two areas of law-namely, the safeguarding and promotion of competition, in the former case, and the creation of legal monopolies, for specific purposes and limited in scope, in the latter case. Many judgments have been delivered since then and a summary or synthesis of the existing case law concerning the controversial interaction between European competition law and intellectual property rights seems to be needed, as is affirmed by John Temple Lang in his remarkable contribution to this issue of the Forum. The author believes that much of the controversy which has occurred was unnecessary and that the significance of several judgments has been misunderstood. The law has developed without any explicit framework, and the Court has never explained the relevant principles comprehensively. In particular, controversy centres on compulsory licensing of intellectual property rights, where the licence in question is the first licence. Where the licence in question is a second or later one, other issues concerning discrimination may arise. Temple Lang suggests that, if the case law is understood in a consistent and rational way, in a case in which a complainant seeks a compulsory licence of an intellectual property right, the complainant needs to prove the following: first, that some identifiable abuse has been committed; second, that harm to consumers has been caused; and third, that a compulsory licence is the appropriate remedy for that abuse. This interpretation, however, necessitates a clearer concept of exclusionary abuse than the one found in 
the Commission's Guidance Paper. ${ }^{8}$ To this end, the author regrets that the Guidance Paper, which discusses exclusionary abuses only, suggests no legal basis, other than a general reference to Article 102 TFEU, for the economic theories suggested therein. Temple Lang, instead, affirms that Article 102(b) provides a comprehensive definition of anti-competitive foreclosure or exclusionary abuse. This means that a complainant needs to show that the alleged abuse is exclusionary and that there is conduct other than the exercise of legitimately acquired intellectual property rights that "limits" the complainant's "marketing, production or technical development". To be illegal, the conduct must "limit" the possibilities open to competitors in some way in which they would not be limited by the mere exercise of the intellectual property rights. Such an approach would not run counter the remedy principle while giving existing case law the possibility of being understood in a consistent and rational way.

\subsection{Car design: in need of a more harmonised and uniform enforcement across the European Union}

Another important issue of particular interest for the development of the European Union internal market concerns car design. As affirmed by Henning Hartwig, in his contribution to this issue of the Forum, although European Union directives and regulations have created harmonised and uniform design law across Europe, national courts still have varied opinions as to how car designs are to be protected. He also highlights that, contrary to what is provided in other jurisdictions, like the United States, where design applications are fully examined prior to registration, in the European Union, Community designs are valid by virtue of registration. Their substantive validity is only challenged upon request. Hartwig identifies some key elements which still seem to be determined, like the scope of prior art and to what degree "similar" designs must differ from each other to receive protection; the difficult task of identifying the correct target audience, due to the vast spectrum covered ${ }^{9}$ the role of experts' opinions - and the almost general consensus against their use, since the "informed user" will probably not be an expert in design; and the obstacles to the protection of spare parts, in particular the fact that, in order for a spare part to qualify for design protection, it needs to be visible "during normal use", which a large number of spare parts are not. As a conclusion to his analysis, Hartwig affirms that the harmonisation of European design law still has a long way to go, despite the general agreement on the content of its rules.

\section{Conclusion}

In his mission letter, in which he invited Professor Mario Monti to write a report on a new strategy for the Single Market, the President of the European Commission, José

\footnotetext{
${ }^{8}$ See, Communication from the Commission-Guidance on the Commission's enforcement priorities in applying Article 82 of the EC Treaty to abusive exclusionary conduct by dominant undertakings, OJ C 45 of 24.02.2009, p. 7.

${ }^{9}$ In Europe, the target audience is usually identified with the "informed user", which suggests a more adult community, as compared to other experiences where the target audience covers "ultimate consumers", which may also include categories with no specific interest.
} 
Manuel Barroso, late in 2009, pointed out that the Single Market, although it has been and remains the cornerstone of Europe's integration and sustainable growth, requires renewed political determination so that it can fulfil all its potential. On that occasion, the European Commission expressed its determination to defend the Single Market through the full use of its enforcement powers, particularly in the areas of the internal market and competition policy, including state aid control. Nevertheless, there is a need for a new awareness of the dramatic consequences that would derive from undermining the Single Market. In fact, if we add to the tensions deriving from the financial and economic crisis those which have occurred more recently in the Euroarea, all this demonstrates even more the need to make full use of the single market as a vector to enhance total factor productivity and competitiveness in Euro-area economics, as expressed by Professor Monti in his Report presented to the President of the European Commission in early May 2010.

To conclude, the proper functioning of the internal market very much depends on the coherent and consistent application of the rules on which it is built, regardless of specific historical and economic contingencies and despite the unsolicited pressure for an eased approach to the application of its rules in time of crisis. Only an effective and sustainable internal market ensures a real space of freedom and opportunity that works for all. 